\title{
Developing Basketball Using TGfU Approach in Elementary Schools
}

\author{
Muhammad Nasihul Waffak \\ Master Program in Sport Sciences \\ Universitas Negeri Yogyakarta \\ Yogyakarta, Indonesia \\ Waffakikor2016@gmail.com
}

\author{
Pamuji Sukoco \\ Faculty of Sport Sciences \\ Universitas Negeri Yogyakarta \\ Yogyakarta, Indonesia \\ Pamuji_sukoco@uny.ac.id
}

\begin{abstract}
-researcher have realized that physical education teachers in elementary schools still make use of the conventional learning technique. For instance, the technique used in learning basketball remains the same as it still follows the usual standards and behaviour. However, this research study aims to develop a basketball learning model using the TGfU approach. This approach consists of development stage, validation test, small-scale test, large-scale trials, and an effectiveness test. Two basketball-expert validations were used in determining the TGfU approach namely: the experts of basketball and basketball lesson. Data obtained, were analysed using descriptive statistics. This technique displayed the model, the ball, and the warming-up strategies associated with the TGfU approach. Students were given Pre-test and post-test effectiveness test to determine their abilities before and after learning. In carrying out the effectiveness test, the researchers made use of the paired t-test method to analyse students' learning outcomes. The result of this research was a basketball learning model which made use of the TGfU approach in the form of a guidebook and a CD. The developed model can improve students' cognitive, affective and psychomotor learning outcomes.
\end{abstract}

Keywords-TGfU approach, basketball, learning outcomes.

\section{INTRODUCTION}

Physical education also known as gym class is a sequence of materials that makes an ideal contribution to our everyday life in an effort to increase the growth and development of students physically and spiritually. Owing to its great importance, physical education should be considered as one of the most important courses in the elementary schools [1].

Physical education learning process consists of teaching methods, time, and learning materials. A learning model can be defined as the way or style used by teachers to convey their messages across to their students in the field and class. Thus, it is important to note that those who wish to develop basketball skills, learn how to do so using basketball materials [2].

The basketball game is a sports game done in groups. A game is carried out between two teams of five players each, with each team competing to gain higher points by shooting the ball into their opponents' ring [3]. To achieve optimum performance, the individual players are requires to possess some technical and tactical skills, express high level of motor abilities, explosive power, speed, and agility.

One or two hands can be used to pass the ball from a player to another. However, adequate care should be taken when doing this to prevent the ball from falling into the hands of an opponent. Players sometimes recklessly pass the ball to their teammate without undertaking some tactics to trick their opponent. [4].

Teachers are expected to select a suitable learning such as the TGfU approach to teach students the game of basketball. According to Chouirnard (2007), TGfU is designed to focus on the development of tactical decision making within the framework of the game [5].

Based on the research findings made on elementary schools, it was gathered that physical education teachers did not make use of the approach model in teaching basketball games rather, they used the conducted conventional learning method. This made the act of learning the game of basketball ordinary using the general standards of behaviours. The absence of an attractive approach model made the game of basketball boring and unexciting to students [6].

This study implies that using a tactical approach to teach students the game of basketball can develop their critical understanding and effective responses to the dynamics and complexity of the game [7].

\section{METHODS}

This research study is a research and development study. This study developed a product used in the learning approach using fifth-grade students of elementary schools. According to Sugiyono (2015), research and development is defined as a method or technique used to produce and test the effectiveness of a particular product. Therefore, this research study is aimed at developing a Teaching Game for Understanding (TGfU) approach in solving the various inconsistencies associated with passing a ball in the game of basketball. Fifth-grade students of Mojolaban Elementary School and Sinduadi Elementary School 1, Mlati Subdistrict, Sleman Regency were the data used in carrying out this research study.

\section{RESUlTS AND DisCUSSIONS}

\section{A. Developing the Design of the Approach in Learning}

The activities undertaken by the researchers in the design and development of the TGfU approach include: (a) observation, (b) interviewing, (c) preparing a work plan, (d) determining product specifications, and (e) determining lesson plans. The work plan was developed and adapted with the development procedures in accordance with TGfU guidelines and the existing guidelines of the elementary school book. The work plan was structured by documenting the product information and by defining the various specifications 
associated with passing, catching, and shooting a ball in the game of basketball.

\section{B. Product-Trial Results}

The trial data used were obtained after a preliminary field studies covering literature studies and field studies was conducted. The development was made up of initial-product analysis and development. Literature studies were conducted by studying the theories related to the research developed, while field studies were conducted by observing the subject conditions.

Research on the initial-product development was carried out by formulating the learning objectives to be achieved, estimating the ability of the researchers in carrying out the research, performing development procedures, and conducting expert validations. After carrying out the development stages above, field trials were conducted.

The validated data obtained from the material experts and practitioners were the initial data used to view and revise the product prior to field trials. The data from the material expert's validation were obtained from the guidelines covering lesson plans, instruments, observation and interview guidelines. The validation was carried out in two stages. The first stage was carried out at the Sports Science Department, of Post-Graduate Programs, Yogyakarta State University (UNY) on December 29, 2017. The total sum of scores of the validation done by the material expert was 70 . If it was performed twenty times, the average score would be obtained by dividing 70 by20 to get a mean value of 3.5 .

\section{The Data Description of the Practitioner's Validation}

The use of TGfU approach to basketball learning, was developed and validated by Mr. Budi Aryanto, a basketball practitioner with the Sports Science Faculty of UNY. The data were obtained in three stages.

The first stage was conducted on December 29, 2017 in the workshop close to the academic service centre of Sports Science Faculty of UNY. In this stage, the practitioner was asked to provide an assessment in the form of responses to the TGfU approach used in learning the game of basketball as developed by the researchers. Their responses were majorly related to the weaknesses of the approach with recommendations for improvement.

The second stage was conducted on January 15, 2018 in the workshop adjacent the academic service centre of Sports Science Faculty of UNY. It was conducted after a product revision in accordance with the results of the first-stage. In the second stage, the validator gave an assessment on the evaluation sheet provided by the researchers. The evaluation sheet was described in accordance with the expert-evaluation indicators by the researcher.

The third stage was conducted on January 24, 2018 in a workshop close to the academic service centre of the Sports Science Faculty of UNY. It was conducted after a product revision was made in accordance with the second validation result. The validator gave an assessment on the evaluation sheet provided by the researchers. The evaluation sheet was described in accordance with the expert evaluation indicated by the researcher.

\section{The Data Description of the Small-Scale Test}

Data for the small scale field trial was obtained from fifthgrade students of Joho Elementary School 3. The technique used to obtain the data was carried out on January 4, 2018. The data obtained were in the form of evaluation with the assessment in accordance with TGfU approach.

\section{1) TGfU Approach}

Based on the small-scale test result obtained which resulted in the evaluation and assessment the techniques used in learning basketball and in accordance with the TGfU approach, the average scores of the three aspects features obtained were 8.04 (technical awareness), 8.05 (decision making), 9.01 (skill execution).

\section{2) Basketball Game}

The average scores of the six techniques used in the game of basketball were 8.04 (passing), 8.05 (catching), 8.01 (shooting), 8.04 (activeness), 8.05 (honesty), and 8.01 (discipline).

\section{E. The Data Description of the Large-Scale Tests}

Based on the obtained results of the small-scale field trial, the TGfU approach developed by the researchers was feasible to be tested into the large-scale test. The large-scale field trials involved the fifth-grade students from two elementary schools. The trials were conducted on January 13 and 15, 2018.

\section{1) TGfU Approach}

The average scores of the technical awareness, decision making, and skill execution were 8,229 8,225, and 8,241 respectively.

\section{2) Basketball Game}

The average scores of the six aspects of the basketball game were 8.24 (passing), 8.24 (catching), 8.23 (shooting), 8.24 (activeness), 8.25 (honesty), and 8.23 (discipline).

TABLE 1. THE RESULTS OF NORMALITY TEST USING LILLIEFORS

\begin{tabular}{|c|c|c|c|}
\hline Variables & $\mathbf{L}$ & $\mathbf{L}_{\text {table }}$ & Categories \\
\hline Pre-test & 0.103 & 0.116 & Normal \\
\hline Post-test & 0.87 & 0.116 & Normal \\
\hline
\end{tabular}

\section{F. Effectiveness test}

\section{1) Data-Normality Test (Lilliefors)}

The normality test was used to find out if the data were normally distributed or not. Fortunately, the data used were normally distributed with a significance score of the pre-test being $0.196>0.05$. Furthermore, the significance score of the post-test was $0.200>0.05$ so that the data normally distributed.

\section{TABLE 2. DESCRIPTIVE STATISTICS}

\begin{tabular}{|c|c|c|c|}
\hline & Mean & Std. Deviation & N \\
\hline Pre-test & 6.2888 & 0.12671 & 58 \\
\hline Post-test & 8.6164 & 0.21304 & 58 \\
\hline
\end{tabular}

\section{2) The Data Description of Paired Sample t-test}

By conducting paired sample test, it was found that the difference between the pre-test and post-test was 2.3276 with an average pre-test score of 6.2888 and an average post-test of 8,6164. The data are described as follows: 


\section{3) Effect size}

TABLE 3. USING THE DATA OF PAIRED-SAMPLE T-TEST

\begin{tabular}{|l|l|}
\hline \multicolumn{2}{|c|}{ d= mean/SD } \\
\hline Numerator & 2.32759 \\
\hline Denominator & 0.24694 \\
\hline Cohen's d & 9.42573 \\
\hline
\end{tabular}

$\mathrm{d}=($ mean $) / \mathrm{SD}$

$=2,32759 / 0,24694$

$=9,4257$

\begin{tabular}{|l|l|}
\hline Size & Interpretation \\
\hline $0-0.20$ & Weak Effect \\
\hline $0.21-0.50$ & Modest Effect \\
\hline $0.51-1.00$ & Moderate Effect \\
\hline$>1,00$ & Strong Effect \\
\hline
\end{tabular}

\section{G. Product Revision}

After the field trials, the learning model developed was revised in accordance with the field-trial analyses. This revision was done during the development process in order to develop a learning model in accordance with the objectives set by the researchers.

\section{H. Material-Expert Validation}

Expert validation was carried out twice with the first stage done on the $29^{\text {th }}$ day of December 2017. During this stage, some weakness were noted which was accompanied by a recommendation for improvement.

- 4 answer-choices should be given in the assessment sheet.

- The basketball in the exercise should be tailored to meet the students' needs.

\section{Practitioner Validation}

- The pattern of the basketball game should be in-line with the Basketball Playbook 012 app.

- The shooting distance in outlined in the learning objectives should be more interesting for the students.

- The words inherent the learning materials should be more self-explanatory and understandable.

The third stage of validation process, was conducted on January 24, 2018. This stage, beams that the instruments should be revised based on the inputs from the practitioner. The draft of TGfU approach model can improve the confidence and cooperativeness of the fifth-grade students of elementary schools. Based on the results of the third-stage validation, the practitioner reassessed the product after which he approved and signed it off after the end of the third stage.

\section{J. Final Product Review}

The final product review of the basketball learning model with TGfU approach can be applied to the fifth-grade students of elementary school. This is used to improve their learning outcomes so that they can perform tremendously during physical education such as passing, catching, shooting. Asides that, it can also instil cooperation and honesty to the students. In this TGfU approach, the students were able to make use of cognitive, affective, and psychomotor skills in the game of basketball such as games, appreciation games, tactics awareness, decision making, skill execution, and performance. Students were still in need of guidance from the teachers to understand the rules associated with playing basketball with TGfU approach.

The learning steps associated with the game of basketball with TGfU approach consists of 6 steps: Game, Game Appreciation, Tactical Awareness, Decision Making, Execution Skill, and Performance. These steps are in line with the scientific method used to identify problems, hypotheses and conclusions.

The efficiency of using learning model with TGfU approach is seen from the time of use and the source of learning. In terms of time, this learning media allows students to play in accordance with the desired time. The developed learning model with TGfU approach can be used as an alternative learning to overcome the limitations of teachers in delivering the materials, giving knowledge about active movement so as to be able to apply the movement in the learning of basketball games.

The factors that affects the learning of the game of basketball using the TGfU approach are the learning environment that provides supports and opportunities for the students to perform active movements in the learning of basketball games. Cheerfulness, sincerity, cooperative opportunity, and honesty also provide a good learning environment for students.

\section{K. Limitations of the Research}

There are many shortcomings associated with mastering and learning the game of basketball such as movements among other things.

The study was limited to the learning of basketball games with respect to passing, catching, and shooting techniques. It was, however, unable to teach all skills associated with the game of basketball games

The study sample used was limited to the fifth-grade students of an elementary school. The existence of shortcomings or limitations of the research conducted by the researchers are expected to be used as a reference for further research.

\section{CONCLUSIONS}

Based on the results of the research and data analysis obtained, the research conclusions are as follows:

a. The researchers made use of 2-1-2 and 2-2-1 gaming strategies to train the students' abilities on how to play basketball. The basketball learning made use of the TGfU approach which was adjusted to the 2013 curriculum. In the game of basketball, the researcher made use of the first three techniques to direct the students. In cognitive aspect, there were five defences and offences. In psychomotor aspect, the researchers observed and assessed the students' passing, catching, and shooting skills. In-line with the affective aspect, the researchers observed and assessed the students' honesty and discipline.

b. The effectiveness test results can be measured by paired sample using the t-test. The researchers also measured the influence of using TGfU approach to analysing the effect and improvement of the students' learning outcomes before 
and after the TGfU approach was utilized. It was also found that TGfU approach can improve students' learning outcomes and the learning of basketball games. This can be seen from the results obtained from analysing the small-scale test, largescale test, and effectiveness test.

\section{ACKNOWLEDGMENT}

The authors would like to thank Yogyakarta State University for their financial support.

\section{REFERENCES}

[1] M. Agus, "Teaching Games for Understanding Tactic Approach." International Journal of Physical Education, 2006, 9, 29, 151.

[2] Autumn, Physical and Health Education Journal. Copyright. 2000 by Allyn \& Bacon. A Pearson Education Company Needham Heights, Massachustts 02194, 2007.

[3] Chouirnard Teaching games for understanding: The importance of student emphasis over content emphasis, 2, 2007. Available: http: //search.proquest.com.ezproxy.ugm.ac.id/docview/21576091/135B89 E41414DCFAA8C/2? Accountid = 13771. Chouirnard (2007: 2)

Teaching games for understanding: The importance of student emphasis over content emphasis. Available: http: //search.proquest.com.ezproxy.ugm.ac.id/docview/21576091/135B89 E41414DCFAA8C/2? Accountid $=13771$.

[4] M. Fathurrohman. Model of Innovative Learning Model, Malamh: ArRuzz Media, 2015.

[5] Muhammad, The Basics of Basketball, Expert Works: Library Experts, 38, 2012.

[6] R. Nancy, Twin Basketball. Jakarta: PT. Raja Grafindo Persada, 168, 2012.

[7] C. Sanata, The Development of Teaching Games for Understanding (TGfU) in Secondary School Students of Class VIII. Essay. Yogyakarta: UNY, 2016.

[8] Caly and S. Nopembri Teaching Games for Understanding (TGfU) (Concepts and Implications in Physical Education Learning) [Electronic Version], 2004

[9] (staff.uny.ac.id/sites/default/files/penelitian/caly-setiawan-msphd/tgfu-konsep-and-implications.pdf, downloaded April 5, 2017).
[10] Sugiyono, Research and Development Methods (Research and Development. Bandung: Alfabeta, 2016.

[11] A. Sukma, Basketball, Jakarta: PT. Raja Grafindo Persada, 2016.

[12] Walton, E. Prayogo \& Lismadiana. (). Development of Basketball Learning Model for Upper Elementary School Children. Sports Journal, 3 (1). 29-38, 2015, Retrieved from http://journal.uny.ac.id/index.php/jolahraga. 